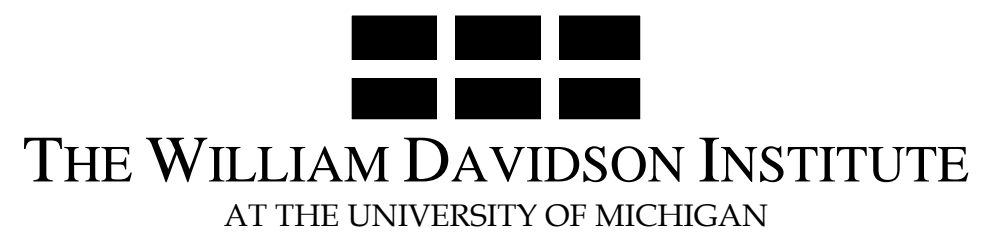

AT THE UNIVERSITY OF MICHIGAN

\title{
CAPITAL INFLOWS, HOUSEHOLD DEBT AND THE BOOM-BUST CYCLE IN ESTONIA
}

By: Zuzana Brixiova, Laura Vartia and Andreas Worgotter

William Davidson Institute Working Paper Number 965 July 2009 


\title{
CAPITAL INFLOWS, HOUSEHOLD DEBT AND THE BOOM-BUST CYCLE IN ESTONIA
}

\section{Zuzana Brixiova,* Laura Vartia ** and Andreas Wörgötter ** 1}

\author{
* University of New York in Prague, Business Department
}

** OECD, Economics Department

From 2000 to 2007, Estonia was one of the fastest growing emerging market economies. A housing boom, fuelled by capital inflows and credit, resulted in skyrocketing house prices and an over-expanded construction sector. However, the currency board limited the Bank of Estonia's ability to curb credit growth, while the fiscal policy framework amplified the cycle through pro-cyclical spending increases and tax cuts. As credit was mostly financed by cross-border loans from foreign banks, the risks of disruptions to credit flows and financial contagion have increased. Some have already materialised through tightened lending standards and capital outflows.

Estonia is now in a severe recession. To restore high and sustainable growth, the country will need to rebalance its resources from non-tradables towards exports. Regaining external competitiveness will be challenging, however, given the fixed exchange rate and recent devaluations in partner countries. Flexibility of the economy will thus be crucial. Over the medium term, policymakers could also strengthen incentives for a better functioning of the housing finance market and gradually remove the pro-cyclical bias of fiscal policy.

Keywords: capital inflows; credit; household debt; boom-bust cycle; Estonia

JEL classification: E3 ; E62 ; C2

1. This paper draws on the analysis carried out for the 2009 OECD Economic Survey of Estonia. During that time Zuzana Brixiova was with the OECD Economics Department. She is now with the University of New York in Prague. The authors thank Christophe André, Andrew Dean, Balázs Égert, Bob Ford, Baudouin Lamine, Sharon Umber, Judit Vadasz, and the Estonian officials for helpful comments, Margaret Morgan for important contributions to the econometric work, and Josiane Gutierrez for excellent editorial support. E-mail addresses: zbrixiova@unyp.cz; laura.vartia@oecd.org ; andreas.woergoetter@oecd.org. 


\section{Introduction}

From 2000 to 2007, Estonia experienced exceptional real GDP growth rates (Figure 1a). The country converged rapidly to the income levels of the euro area, with living standards exceeding those in most new members of the European Union.

However, growth was unbalanced and driven by an overexpansion of non-tradable sectors, particularly real estate and construction. It was financed by large capital inflows, which led to unsustainable current account deficits and high private debt. External financing became a key source of rapid credit growth, mainly to households for real estate purchases in the form of variable interest rate and foreign currency loans. Pro-cyclical fiscal policy and wages amplified the cycle.

In addition to the liquidity risk, the predominance of cross-border loans from the Nordic banks has exposed Estonian banking sector to foreign exchange and contagion risks. Since the Estonian banks have financed most of the long-term mortgage loans by short-term borrowings in euros from their parent banks, maturity mismatch also became a concern.

Growth came to an abrupt halt starting at end-2007, when some of these risks materialized. Specifically, the Nordic lenders reassessed risks related to the Estonian economy's prospects and high private sector indebtedness, and tightened lending conditions. This trend, which was amplified by rapidly declining domestic demand and plummeting consumer confidence, resulted also in lower demand for credit. To exacerbate this downward trend in economic growth, exports were hit by the collapse of demand for imports among the main trading partners at end-2008.

Being now in a severe recession, Estonia is facing its most challenging situation since the early 1990s. Restoring high and a sustainable growth will require regaining external competitiveness, which will be challenging given the exchange rate regime and recent devaluations in partner countries. Increasing flexibility of the economy is thus crucial. In addition, the pro-cyclical fiscal policy should gradually evolve into a rule-based countercyclical one. Policy makers could also phase out distortions in the housing finance market that amplified the cycle. 
Figure 1a. Estonia and emerging market economies: GDP growth and inflation

Average annual \% change, 2000-07

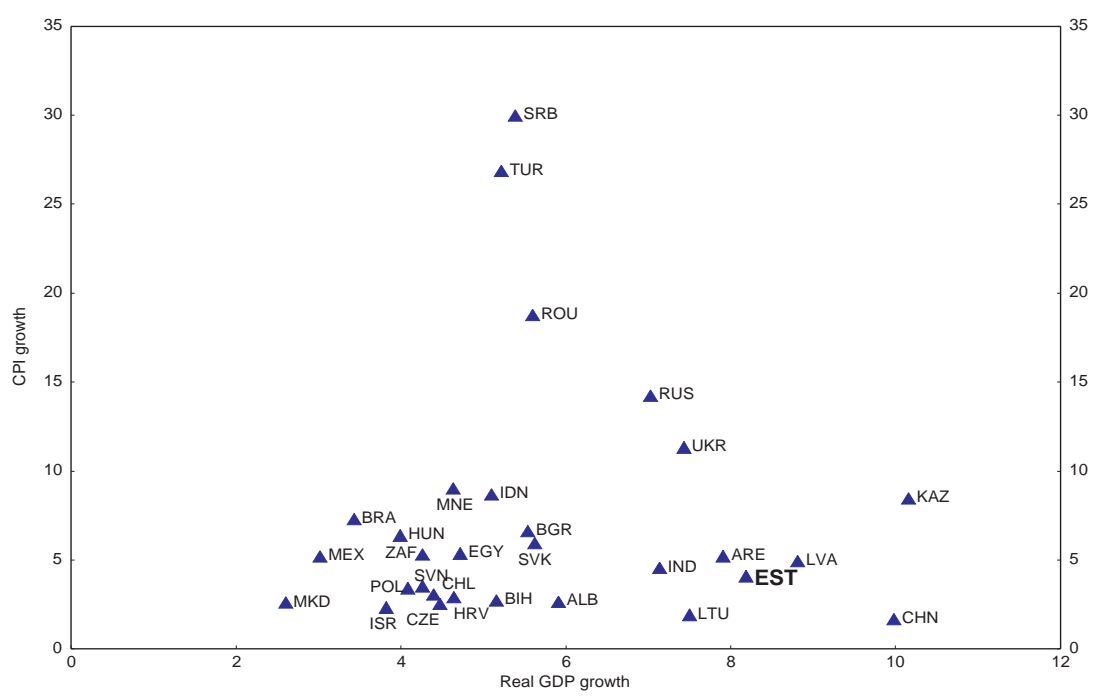

Figure 1b. Real GDP, domestic demand and private sector credit

Annual change, \%

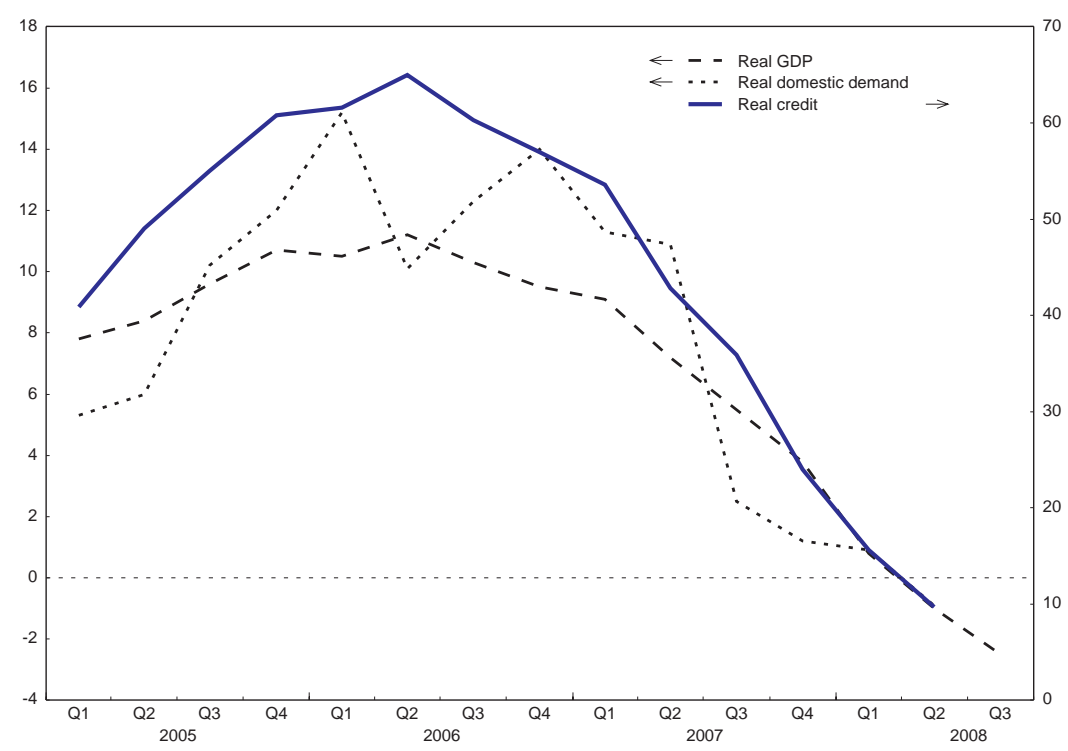

Source: Bank of Estonia; OECD Economic Outlook database; IMF WEO database.

The paper is organized as follows. Section II summarizes the current economic challenges; Section III provides an overview of the trends and drivers of capital inflows; Section IV summarizes the household debt accumulation and its implications; Section V discusses options for developing housing finance market; and Section VI concludes. 


\section{Estonia's boom turned into bust}

During the period between 2000 and 2007, Estonia's output grew faster than in most emerging market economies. Between 2005 and 2007, however, the real GDP growth accelerated even more rapidly and signs of overheating appeared: GDP grew above its trend, labour shortages emerged, inflation rose, and current account deficits surged to unsustainable levels.

\section{Growth collapsed in 2008 and is projected to regain strength only in 2011}

Since 2008, the economy has been experiencing a hard landing, largely unwinding a loanfinanced over-expansion of domestic demand. Real GDP contracted by 3.6\% in 2008 compared to 2007, due to a collapse of domestic demand and a slowdown of foreign-financed credit (Figure 1b). Exports were also hit at the end of 2008 due to the economic slowdown in the euro area. Growth is projected to pick up gradually in 2010 and regain strength only in 2011 (OECD, 2009a).

The ongoing recession was triggered by a combination of declining real estate prices and a tightening of credit. Even though the current account imbalances of preceding years called for a correction, the speed and size of the output adjustment were faster and deeper than expected. The slowdown has brought about a deterioration of the fiscal balance, which in 2008 resulted in the first significant budget deficit since the Russian crisis in 1998. Unemployment has increased rapidly, putting an end to years of steady decline. On the positive side, the current account deficit has narrowed, and the annual (year-on-year) CPI inflation has decelerated.

During the boom, output and employment shifted disproportionately to the non-tradable sectors and led to external imbalances that have narrowed somewhat only recently. To restore growth, Estonia will need to shift production from non-tradables (such as construction and housing) to export sectors. Competitiveness thus will need to be restored, including through enhancing flexibility of labour and product markets. ${ }^{2}$ However, the inherited real exchange rate appreciation of the Estonian kroon and devaluation in partner countries will make the necessary export-driven recovery more challenging. The speed of recovery will depend on how quickly the main trading partners, especially the euro area, will rebound from recession. ${ }^{3}$

\section{External vulnerabilities remain, but there are mitigating factors}

Estonia's domestic financial system is dominated by commercial banks. In fact, the entire banking sector is privately owned, of which the majority is foreign-owned. The market concentration is high, with the four largest banks (Swedbank, SEB, Sampo, and Nordea, all foreign-owned) accounting for more than $95 \%$ of the financial market, as measured by total assets at end-2007.

2. Chapters 4 and 5 in OECD (2009a) discuss measures to increase labour and product market flexibility in Estonia.

3. Reinhardt and Rogoff (2008) examine past banking crises in OECD countries and find that they often follow housing booms. GDP growth remains weak several years after the crisis, which could complicate the global recovery. 
While financial integration has brought the Estonian economy significant benefits, it has also raised concerns about contagion risks from international financial markets. The strong presence of foreign - mostly Nordic - banks has increased Estonia's dependence on cross-border credit and vulnerability to its reversals due to changes in parent banks' risk assessment. The global crisis has already affected the Estonian banking sector and the economy through tighter lending standards.

The liquidity risk of the banking sector materialised in the fall of 2008 with a run on one of the major Nordic banks, but the situation stabilized due to swift action of the home country central bank (IMF, 2009). In February 2009, the Bank of Estonia signed a precautionary agreement with the Swedish Central Bank that guarantees its access to extra liquidity, if needed. The agreement thus reduces the liquidity risk by strengthening the Bank of Estonia's capability to add funding to the banking sector. One of the remaining risks is then whether the Nordic banks would be able to provide sufficient financing.

The predominance of variable-rate loans in foreign currency is adding to financial vulnerabilities, which is already high due to rising unemployment and declining real estate prices (Table 1). The relatively high stock of short-term external debt has also been of concern. ${ }^{4}$ However, in addition to the precautionary agreement with the Riksbank, the liquidity risk has been reduced by the rapidly narrowing current account deficit, which is increasingly financed by the EU structural funds. ${ }^{5}$

Table 1. Macroeconomic and financial indicators in selected emerging market economies

\begin{tabular}{|c|c|c|c|c|c|}
\hline & \multirow{2}{*}{$\begin{array}{c}\begin{array}{c}\text { Foreign bank } \\
\text { credit (\% of host } \\
\text { GDP) }\end{array} \\
\text { End-2007 }\end{array}$} & \multicolumn{2}{|c|}{$\begin{array}{c}\text { Current account balance } \\
\text { ( } \% \text { of GDP) }\end{array}$} & \multirow{2}{*}{$\begin{array}{l}\begin{array}{c}\text { Private-sector } \\
\text { credit }\end{array} \\
\text { Year-on-y }\end{array}$} & \multirow{2}{*}{$\begin{array}{l}\text { Inflation } \\
2008^{2}\end{array}$} \\
\hline & & 2007 & $2008^{1}$ & & \\
\hline Estonia & 161.7 & -18.1 & -10.8 & 21.5 & 11.1 \\
\hline Bulgaria & 90.4 & -21.4 & -24.4 & 54.5 & 14.5 \\
\hline Hungary & 87.0 & -5.0 & -5.5 & 18.0 & 6.7 \\
\hline Latvia & 125.5 & -22.9 & -15.1 & 22.2 & 16.7 \\
\hline Lithuania & 92.4 & -14.6 & -14.9 & 36.4 & 12.2 \\
\hline Poland & 51.1 & -3.8 & -4.7 & 29.5 & 4.8 \\
\hline Romania & 50.6 & -14.0 & -13.8 & 62.0 & 9.0 \\
\hline
\end{tabular}

1. Estimates, IMF WEO database, October 2008.

2. Latest available observation in 2008.

Source: IMF (2008).

$4 \quad$ According to the Bank of Estonia, the external debt was $125 \%$ of GDP, with the short term debt accounting for $50 \%$ of GDP at end-2008.

5. In response to the global financial crisis, Estonia raised the deposit insurance limit from 20000 to 50000 euros in October 2008 to increase confidence in the banking sector. 


\section{Capital inflows and the credit boom during 2000-07: drivers and consequences}

\section{Large capital inflows fuelled growth but led to external imbalances and loss of competitiveness}

The growth acceleration between 2000 and 2007 was driven mostly by domestic demand, and especially by a private investment boom (Table 2). Since 2003, the bulk of investment took place in the non-tradable sector, in particular in the residential housing and the construction sector. In contrast to the central European countries where growth was driven more by exports, in Estonia and the other two Baltic countries (i.e. countries with fixed exchange rate regimes), domestic demand and investment growth outpaced real GDP growth by wide margins. However, the concentration in construction and dwellings indicates that investment in these countries has not directly raised productivity, export capacity, or competitiveness. ${ }^{6}$

Table 2. Sources of domestic demand changes during 2000-07

Percentage points of GDP

\begin{tabular}{|c|c|c|c|c|c|c|}
\hline & \multirow{2}{*}{$\begin{array}{c}\text { Domestic } \\
\text { demand/GDP }\end{array}$} & \multicolumn{2}{|c|}{ Investment/GDP } & \multicolumn{3}{|c|}{ Consumption/GDP } \\
\hline & & Total & $\begin{array}{l}\text { Dwelling, res. } \\
\text { construction }\end{array}$ & Total & Private & Public \\
\hline Estonia & 6.6 & 9.3 & 9.8 & -2.6 & 0.1 & -2.6 \\
\hline Latvia & 11.7 & 12.1 & 6.1 & -0.5 & 2.5 & -3.0 \\
\hline Lithuania & 7.1 & 11.5 & 8.2 & -4.6 & 0.0 & -4.5 \\
\hline Czech R. & -8.1 & -2.9 & 0.5 & -5.1 & -4.4 & -0.7 \\
\hline Hungary & -5.1 & -6.8 & $\mathrm{n} / \mathrm{a}$ & 1.6 & 1.5 & 0.2 \\
\hline Poland & -3.7 & -1.1 & -0.6 & -2.7 & -3.2 & 0.6 \\
\hline Slovak R. ${ }^{1 /}$ & -1.3 & 1.7 & 0.6 & -2.9 & -0.2 & -2.8 \\
\hline
\end{tabular}

1. Dwellings and other buildings.

Source: Ameco statistical database (2008).

The investment boom was financed by capital inflows, which reflected a benign international environment combined with Estonia's liberalised capital account and the currency board. As foreign banks under-priced risks due to their overly-optimistic assessment of Estonia's growth prospects, the inflows led to unsustainable current account deficits. In fact, starting from already high deficit in the 1990s, Estonia's current account balance deteriorated faster than those of most emerging market countries (Figure 2a).

The widening current account deficit has been financed increasingly by loans. As a consequence, the stock of private external debt rose above $100 \%$ of GDP at the end of 2007. The debt built up has worsened Estonia's net international investment position relative to Central European countries, with the exception of Hungary (Figure 2b). In addition, the capital inflows led to inflationary pressures, real exchange appreciation and erosion of competitiveness, and pressures on the fixed exchange rate regime (Hegerty, 2009).

6. Lamine (2008) carried out a sectoral breakdown of the real value added and TFP growth during 2005-07 and found that manufacturing and financial intermediation registered high total factor productivity growth, while productivity growth in construction and real estate declined. 
Figure 2a. Current account deficits in emerging market economies

$$
\% \text { of GDP }
$$

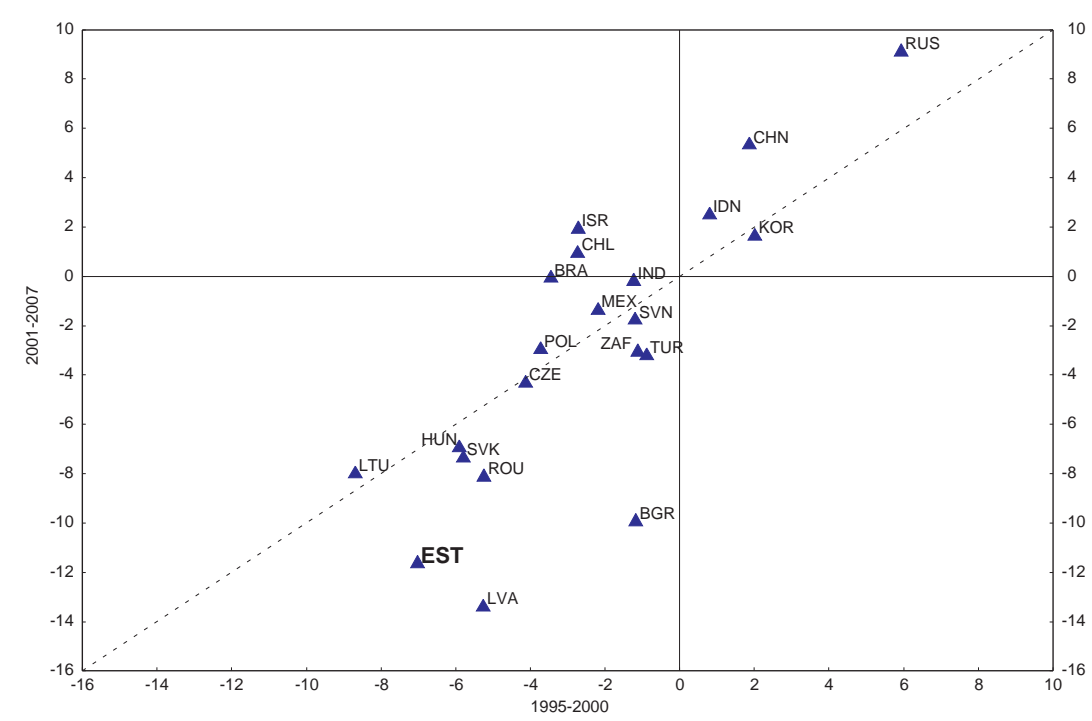

Figure 2b. Net international investment positions: Estonia and Central Europe, 2001-06

(Per cent of GDP)

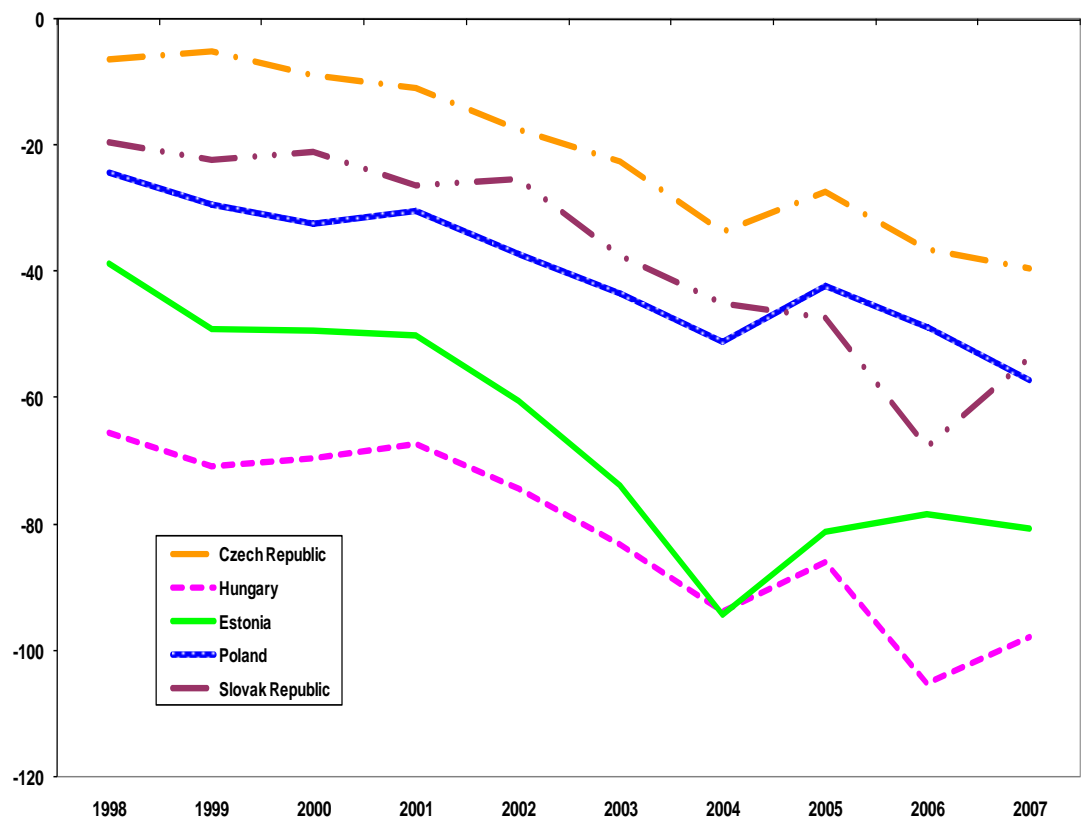

Source: IMF IFS database (May 2009). 


\section{... and were mirrored in the credit boom}

Private-sector credit surged between 2000 and 2007, starting from a low base even relative to most other European emerging market economies (Figure 3a). The currency board locked in low real interest rates, but also other factors such as income growth and general optimism due to EU accession contributed. The significant credit market liberalization and financial integration are often mentioned as additional factors that fueled credit booms but also the high GDP growth. ${ }^{7}$

By end of 2007, the share of private sector credit in GDP in Estonia was one of the highest among the European emerging market economies. As liabilities of banks and foreign branches operating in Estonia increasingly consisted of parent banks' loans rather than domestic deposits, the banks' net foreign asset positions deteriorated and loan-to-deposits ratios increased (Table 3). These developments in the banking sector raised concerns about the quality of the loan portfolio and its financing, and especially raised fears about Estonia's vulnerability to reversals in credit due to changes in Nordic banks' risk assessment. The global financial crisis has affected the Estonian banking sector through higher cost of borrowing, tighter lending standards, and reduced foreign credit.

Table 3. Financing of the credit growth, 2000-07

(Changes in the ratios, in percentage points of GDP)

\begin{tabular}{lcc}
\hline & $2000-04$ & $2005-07$ \\
\cline { 2 - 3 } Bank credit to the private sector & 5.9 & 11.0 \\
Bank credit to the public sector & 0.1 & -0.2 \\
Net foreign liabilities & -0.3 & 8.4 \\
Bank deposits & 1.9 & 3.9 \\
Other net liabilities & 4.4 & -1.5 \\
\hline
\end{tabular}

Source: Bank of Estonia.

Searching for profits, Nordic banks took increased risks, probably due to the fact that their exposure in Estonia was a small part of their total portfolios. Accordingly, they set nominal interest rates at the same levels as in their home markets. With a rise in local inflation, real interest rates turned negative for Estonian borrowers and demand for credit increased. However, the high risk tolerance of the Nordic banks has reflected an underestimation of the risks pertaining to the Estonian economy and relied on overly optimistic growth expectations. The banks also most likely overestimated the liquidity or collateral value involved in higher-risk loans.

The rapid credit growth was also encouraged by improved scores from some credit rating agencies between 2001 and 2007. Responses of the credit agencies to the downturn seem more measured as only one downgraded Estonia more than the economic fundamentals seem to justify.

$7 \quad$ Tornell and Westermann (2005) illustrate that in the middle-income countries with credit market imperfections, including limited contract enforceability, financial liberalization leads to more rapid growth. However, this higher growth is not smooth, but takes place through booms and busts. 
In general, research on cyclical properties of credits ratings in emerging market countries points to their procyclicality. ${ }^{8}$

Household credit expanded particularly rapidly, especially between 2004 and 2007, and the sectoral composition of total credit shifted to mortgages and real estate. ${ }^{9}$ As a result, real estate prices skyrocketed (below), making Estonia vulnerable to a sharp correction in the real estate market, which has materialized. About $80 \%$ of all domestic loans were extended in foreign currency and funded by short term euro loans from parent banks, raising liquidity risk. The currency mismatch in the households (and corporate) balance sheets, together with the low level of international reserves, has made local borrowers subject to exchange rate risk. ${ }^{10}$ This risk underscores the importance of maintaining the currency board at the prevailing rate.

Throughout this period, Estonia faced challenges in cross-border coordination of banking supervision with the Nordic counterparts. It has been recognized that the mostly nationally-based supervisory systems and safety nets often do not capture negative externalities involved in crossborder supervision. Coordination and enhanced information sharing between the host and home country supervisory institutions are hence required for effective supervision and regulation (Gulde, 2005; Schoenmaker and Oosterloo, 2006; Eisenbeis, 2006; and OECD, 2009b). Towards this goal, the Estonian Financial Supervision Authority signed agreements - in the form of Memoranda of Understanding - with foreign supervisory bodies in the Nordic countries. ${ }^{11}$

The currency board arrangement, in place since 1992, contributed to the credit growth. While the arrangement has served Estonia well over the years, especially as a guarantee of commitment to prudent macroeconomic policies during transition, it constrained the Bank of Estonia's ability to curtail credit growth. Measures which the Bank adopted, such as an increase in the minimum reserve requirement ratio, were mostly of a signaling nature and had minimal actual impact. ${ }^{12}$ Lending conditions and bank lending in Estonia were highly pro-cyclical in recent years (Figure 3b).

8. For example, Ferri et al. (1999) found pro-cyclical behavior of the rating agencies during the Asian crisis, while Kaminsky et al. (2004) found that ratings tend to be pro-cyclical for the middle-income countries in general. Regarding procyclicality of credit ratings in the United States, utilizing annual data on all US firms rated by Standard \& Poor's, Amato and Furfine (2004) found no evidence that ratings would exhibit excess sensitivity to the business cycle. More recently, however, Pagano and Volpin (2009) argue that rating inflation contributed to the boom and bust of the market for the asset-backed securities.

9. At the end of 2007 , mortgages accounted for $40 \%$ of total credit to the private sector and real estate related business activities for another 25\% (IMF, 2009).

10. However, the foreign exchange and liquidity risks are mitigated by the fact that most of the exposure of the Estonian banks is to Nordic parent banks, shifting the liquidity risk to contagion should the parent institutions themselves experience major funding difficulties on international markets (IMF, 2009; and Ross, 2009). In addition, foreign banks replaced an exchange rate risk with a credit risk.

11. The recent IMF Financial Sector Assessment Program and Update concluded that there are no serious weaknesses in Estonian bank supervision and regulation (IMF, 2009).

12. The additional reserves created now provide an extra buffer and strengthen the financial sector. Together with the minimal public debt, they distinguish Estonia from Latvia and Lithuania. 
Figure 3a. Private sector credit growth in emerging market economies, 2001-07 (Change in credit-to-GDP ratio)

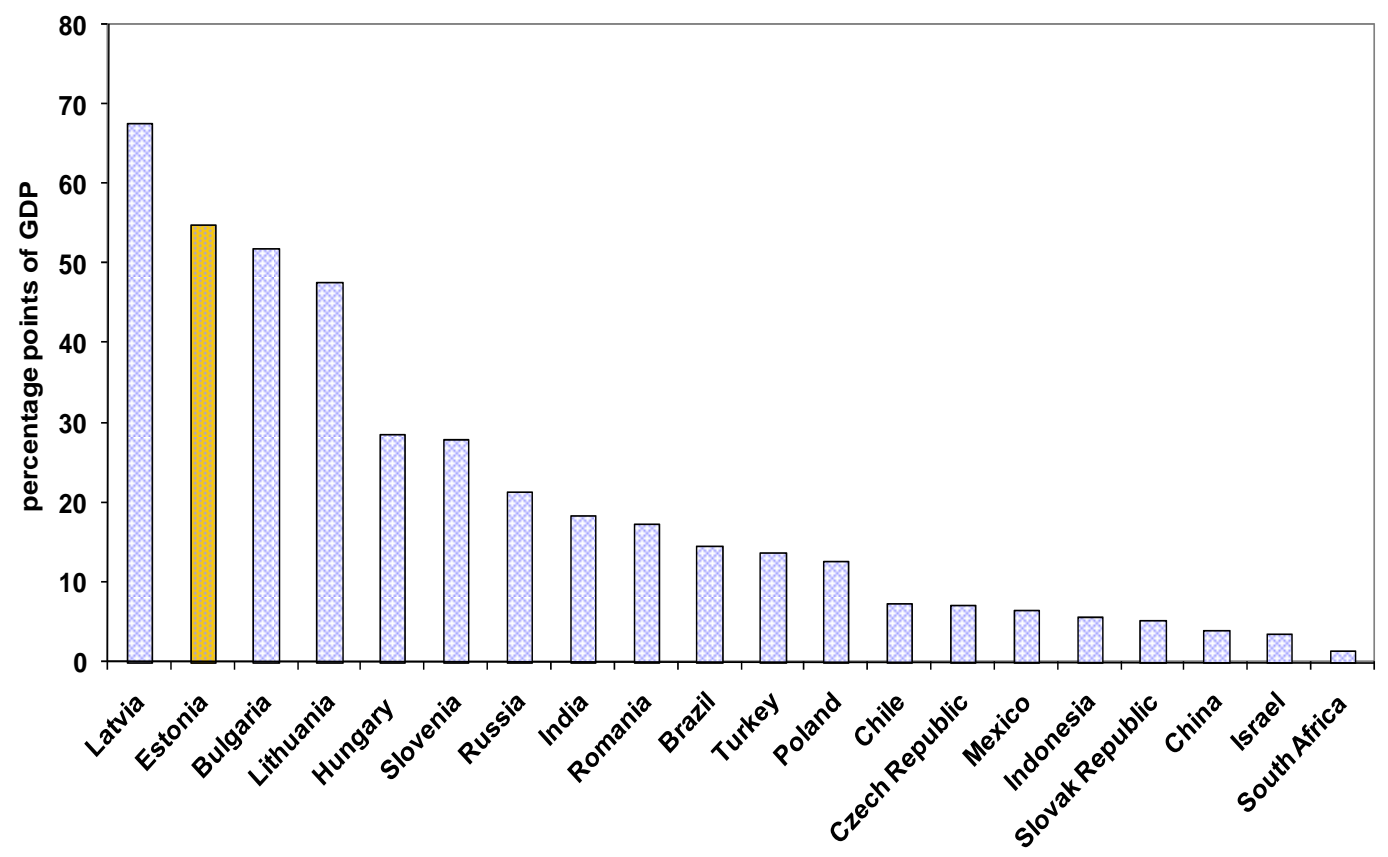

Figure 3b. Correlations of the cyclical components of real interest rates and real GDP ${ }^{1 /}$ 0 to \pm 1 indicating increasing positive/negative correlation

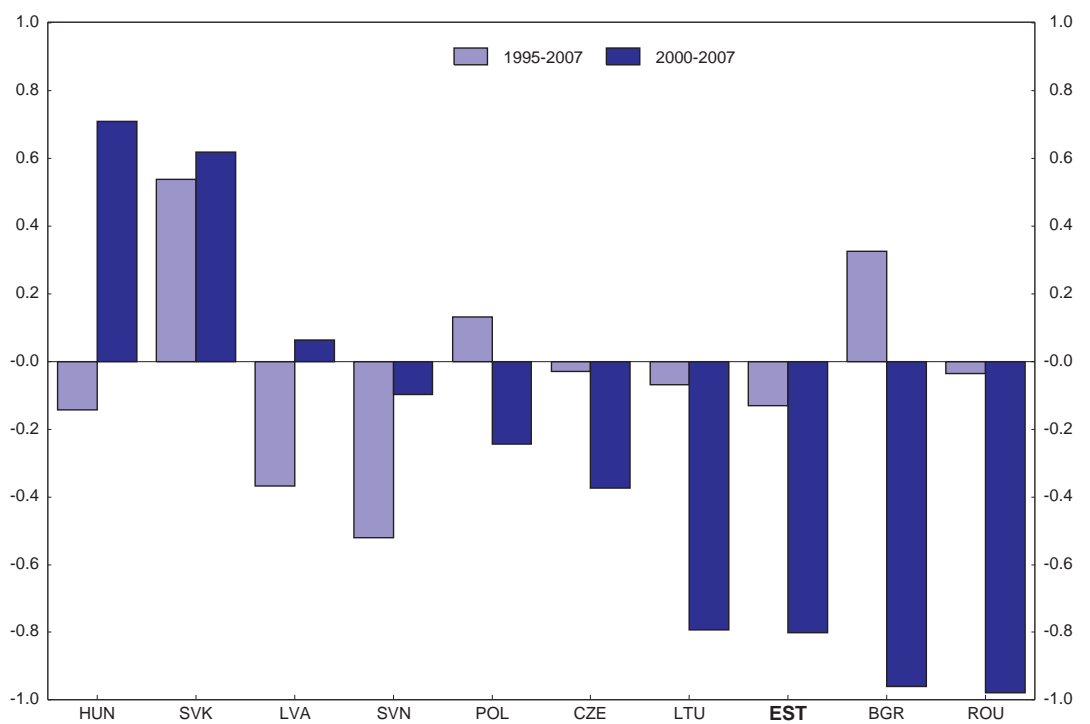

1. The cyclical component is obtained from HP-filtered data for 1995-2007 from the Eurostat and the IMF IFS. Source: IMF World Economic Outlook, IFS, and the Bank of Estonia. 


\section{...and were also reflected in skyrocketing house prices}

House price increases in Tallinn between 1997 and mid-2007 were striking - prices rose by $500 \%$ in nominal terms. Such increases seem comparable to (or even above) countries that experienced major house booms such as Ireland or the UK. ${ }^{13}$ Specifically, nominal house prices in Ireland increased by 340\% between 1992 and 2006 and in the UK by 200\% between 1998 and 2007.

House prices in Estonia increased particularly rapidly between 2004 and 2006, growing faster than in most OECD countries, the Nordic neighbours, and regional peers such as Slovenia (Table 4). Similar to the UK and Ireland, the decline of house prices from their peaks was also abrupt in Estonia, amounting to more than a 30 percent decrease between mid-2007 and the 4th quarter of 2008.

Table 4. Real house price changes and some of the underlying factors, 2004-06 ${ }^{1}$

\begin{tabular}{lcccc}
\hline & $\begin{array}{c}\text { Real house } \\
\text { prices }^{2}\end{array}$ & $\begin{array}{c}\text { Real GDP growth, } \\
\text { 2002-06 }\end{array}$ & $\begin{array}{c}\text { Real mortgage } \\
\text { rates }^{3}\end{array}$ & $\begin{array}{c}\text { Housing loans to } \\
\text { GDP }^{4}\end{array}$ \\
\cline { 2 - 5 } Estonia & $\mathbf{2 3 . 0}$ & $\mathbf{8 . 4}$ & $\mathbf{0 . 1}$ & $\mathbf{1 6 . 8}$ \\
Slovenia & 10.3 & 4.2 & 3.6 & 3.6 \\
Finland & 6.1 & 3.0 & 2.6 & 5.8 \\
Ireland & 9.2 & 5.5 & 1.5 & 13.3 \\
Spain & 10.2 & 3.3 & 0.3 & 15.8 \\
Sweden & 9.0 & 3.2 & 1.9 & 5.9 \\
\hline
\end{tabular}

\footnotetext{
Based on the European Central Bank (2003), Table 2.4.

Average annual growth rates, in \%. For Estonia, only Tallinn prices were used.

Average over the period, in percent.

Cumulative change in percentage points.

Source: ECB; Hypostat, 2008.
}

\section{Drivers of house prices in Estonia}

Utilizing an empirical model, the sections below analyze factors underlying Estonia's house price increases between 1997 and 2007, to determine whether they were similar to other countries that have experienced housing booms. The results also shed light on causes of the recent sharp decline. In the UK, the growth of house prices was due to population growth, rising incomes, and low interest rates, and amplified by the loosening of mortgage credit conditions (Kuenzel and Bjornbak, 2008). In Ireland, favourable tax treatment of residential property was also an important driver of house price inflation (Malzubris, 2008).

The econometric analysis is based on a standard framework where house prices are determined by housing supply and demand in the long run, as in Meen (2002), Jacobsen and Naug (2005) and others. Demand is captured by households' real disposable income and the housing cost per representative house owner. Supply, which is relatively stable in the short run, is measured by the available housing stock per person. Households' income and housing stock per person were rising during most of the years between 1997 and 2007, while interest rates were decreasing.

13. Even though Estonia wide prices are not available, Tallinn price increases give some indication. 
More formally, in the underlying theoretical framework house prices are determined by housing supply and demand in the long run. The housing demand function described by (1) and (2):

$$
H^{D}=f\left(\frac{V}{P}, Y\right) \text {, where } f_{1}<0, f_{2}>0
$$

where $H^{D}$ is housing demand, $V$ total housing cost for a representative house owner, $P$ index of prices of goods and services other then housing, and $Y$ households' real disposable income. $^{14}$ The housing cost for an owner-occupier is the value of goods foregone because of owning and occupying a dwelling:

$$
\frac{V}{P}=\frac{P H}{P} B K=\frac{P H}{P}[i(1-\tau)-\pi]
$$

where $P H$ is the nominal price of an average dwelling, $B K$ is the user cost (real after tax housing loan interest rate), $i$ is the nominal interest rate, $\tau$ is the income tax rate, and $\pi$ is the inflation rate. The housing supply, denoted $H$, is stable in the short run. $P H$ equates housing demand and supply.

Empirical estimation of the above framework is carried out using the time series of quarterly data on house price and housing loan interest rate deflated by consumer prices from mid-1997 to early 2008. The quarterly dwelling stock series were obtained by extrapolating of data on completed dwellings. All variables except the interest rate are in logarithms. ${ }^{15}$ An error correction model, capturing the long-run determinants of house prices and short-run dynamics, is utilized. The focus is on the long-run results as this allows for the analysis of main factors driving house prices over the medium term. ${ }^{16}$

Table 5 summarises the main results. ${ }^{17}$ It shows that, indeed, house prices over the long run are explained mainly by increased household income and very low real after tax interest rates whereas the lack of housing supply does not seem to have been a major factor determining house price growth. This can be partly explained by the slow response in the total available housing dwellings to price changes, consistently with evidence for OECD countries (OECD, 2008 and 2006, and others).

14. This section draws on Meen (2002), Jacobsen and Naug (2005), and Égert and Mihaljek (2007). Demand for housing rises with income and decreases with housing cost.

15. Standard unit root test indicate that all the variables are non-stationary, i.e. there may exist a co-integration relationship between them.

16. The error correction model is estimated using: i) Engle-Granger two-steps approach; ii) the two-step approach with dynamic OLS; and iii) estimating an error correction model using the auto-regressive distributed lag (ARDL).

17. The error correction term is negative in all the estimations showing that differences between actual and the long-run house prices based on key are corrected over time. The adjustment of actual house price to their long-run level is relatively rapid in the Estonian housing markets, i.e. the error correction term is large. 
Table 5. Results for house price regressions

\begin{tabular}{l|ccc}
\hline & OLS & DOLS & ARDL \\
\hline real disposable income & $1.76^{\star \star \star}$ & $2.10^{\star \star \star}$ & $2.00^{\star \star}$ \\
& $(3.5)$ & $(3.3)$ & $(2.1)$ \\
real after-tax mortgage rate & $-2.84^{\star \star \star}$ & $-2.24^{\star \star}$ & $-2.31^{\star}$ \\
& $(-2.9)$ & $(-2.2)$ & $(-1.8)$ \\
housing stock per person & 0.01 & -3.02 & -1.81 \\
& $(0.0)$ & $(-0.4)$ & $(-0.2)$ \\
ECT & $-0.83^{\star \star \star}$ & $-0.66^{\star \star \star}$ & $-0.85^{\star \star \star}$ \\
& $(-5.7)$ & $(-4.3)$ & $(-4.5)$ \\
\hline No. obs. & 40 & 40 & 40 \\
\hline adjR2 & 0.48 & 0.34 & 0.42 \\
\hline
\end{tabular}

The response of house prices to income changes is fairly high. The estimated income elasticity is around two, i.e. a $1 \%$ increase in income leads to around a $2 \%$ rise in prices. This is somewhat higher than recent OECD estimates for Ireland and Sweden - two small open economies that have also experienced a housing boom. The effect of a one percentage point increase in the after-tax interest rate is estimated to vary between 2 to $3 \%$ which is close to OECD estimates for Ireland, and Netherlands (OECD, 2006; 2007; and 2008).

As Table 5 shows, households' real disposable income and real after-tax interest rate have the expected signs and are statistically significant, but the housing stock is not statistically significant in any of the specifications. ${ }^{18}$ The results are robust to change in the estimation method. All estimations include constant and seasonal dummies.

To check the robustness of the results, several different specifications were estimated. Specifically, to capture the impact of potential first-time buyers, the population for the 25 to 29 age group was considered and the housing stock was divided by the number of persons in this age group (OECD, 2006a; OECD 2006b; and OECD, 2009b). The quarterly population series for the age group 25-29 were derived by linear extrapolation and using quarterly data on age groups in EuroStat Labour Force Survey. In addition, real wages were considered instead of real disposable income. Finally, the effect of differences in the period of analysis was examined. The results are relatively robust to these changes in the baseline specifications.

In sum, house prices in Estonia have been driven by: i) rapidly rising disposable incomes related to steep GDP and wage growth, declining tax rates; and ii) a fall in after-tax interest rates during the first half of the decade. ${ }^{19}$ Overly optimistic expectations about future house price rises are not explicitly captured in the above analysis, but inevitably played a role during the upturn, while negative perceptions have exacerbated the downturn. ${ }^{20}$

18. Excluding the housing stock as a regressor does not change the results pertaining to the households' income and after-tax interest rate.

19. It is common to assess to what extent these increases were driven by underlying fundamentals (interest rates, income) and to what extent houses were overvalued. From late 2005 until early 2007 the actual house prices were estimated to be above their fundamentals by 5 to $10 \%$. The gap between the actual prices and fundamentals is smaller than is estimated for other countries, for example in IMF (2008), pointing to uncertainties surrounding such estimates. In Estonia the fundamentals themselves have been distorted due to imperfections in credit and labour markets.

20. For discussion of how expectations of price increases lead to actual increase in house prices that are not related to fundamentals, see White (2006) and Jacobsen (2005). 


\section{Procyclical wages amplified the business cycle...}

In addition to lending conditions, Estonia's policymakers faced pro-cyclical wage growth. Rapid credit and wage growth of recent years stimulated domestic demand, and was reflected in the pro-cyclical private consumption and output volatility. Output and private consumption in Estonia were more volatile (measured by relative standard deviation) than, on average, output and private consumption in other European emerging market economies (Table 6).

Table 6. Business cycle properties of wages, credit and private consumption, 1995 - 2007

\begin{tabular}{lccccc}
\hline \multirow{2}{*}{ Country } & \multicolumn{2}{c}{$\begin{array}{c}\text { Relative standard deviation } \\
\text { (in \% of the mean) }\end{array}$} & & \multicolumn{2}{c}{ Correlations with output } \\
\cline { 2 - 6 } & Output & Private consumption & $\begin{array}{c}\text { Wage } \\
\text { growth }\end{array}$ & $\begin{array}{c}\text { Private } \\
\text { consumption }\end{array}$ & $\begin{array}{c}\text { Private sector } \\
\text { credit }\end{array}$ \\
\cline { 2 - 6 } Czech Republic & 13.5 & 12.2 & 0.12 & 0.78 & 0.84 \\
Estonia & $\mathbf{3 0 . 6}$ & $\mathbf{2 7 . 9}$ & $\mathbf{0 . 5 2}$ & $\mathbf{0 . 9 5}$ & $\mathbf{0 . 9 2}$ \\
Hungary & 17.9 & 17.9 & -0.20 & 0.73 & 0.59 \\
\hline
\end{tabular}

1/ Correlation of real wage growth with the Eurostat's output gap. Source: Authors' calculations.

\section{...and so did procyclical fiscal policies}

With the currency board and a liberalized capital account, fiscal policy is the only remaining tool of macroeconomic management. However, instead of mitigating the cycle, fiscal policy amplified it.

Since the early 1990s, when the currency board was introduced, the government adhered to the rule of annually balanced budgets. While the fiscal discipline contributed to Estonia having a stronger fiscal position than most OECD and European emerging market countries (Figures 4a and 4b), such rules have been criticized for increasing output volatility and creating pro-cyclical bias (Fatas, 2005; and European Commission, 2006). Indeed, estimates of the Estonian cyclically adjusted budget balance suggest that fiscal stance has been pro-cyclical or neutral every year since 2000 (European Commission, 2008). ${ }^{21}$

An alternative way to evaluate the fiscal cyclical stance is through changes in government consumption and tax rates (Kaminsky et al., 2004). According to this approach, tax policy has been pro-cyclical in recent years, as tax rates on both personal and corporate income were gradually lowered from 2004 onwards, while the other rates remained unchanged. ${ }^{22}$ The cyclical component of real government consumption was positively correlated with the cyclical component of real GDP between 1995 and 2007, suggesting that expenditures amplified procyclical lending conditions and wages (Figure $4 \mathrm{c}$ ). ${ }^{23}$

21. The estimates are based on the output gap and do not classify revenues associated with the absorption boom as cyclical. They underestimate the fiscal loosening of recent years (Jaeger and Klemm, 2007).

22. The pro-cyclical stance continued in 2009 with the postponed cut of personal and corporate income tax rate, while the reduced VAT rate on selected items increased.

23. Kaminsky et al. (2004) found that in the emerging market countries spells of capital inflows are associated with expansionary macroeconomic policies while outflows with contractionary ones. 


\section{Reassessment of the household debt sustainability put a break on the housing boom}

Shocks to asset prices alter the value of collateral and hamper borrowers' ability to borrow, thus amplifying credit cycles (Kiyotaki and Moore, 1997). With high indebtedness, Estonian households are particularly vulnerable to tighter lending conditions, especially in combination with income and house price declines (ECB, 2003). This section discusses the causes and characteristics of high household debt in Estonia, its macroeconomic implications, and mitigating factors.

Figure 4a. Fiscal balance, 2003-07

$\%$ of GDP

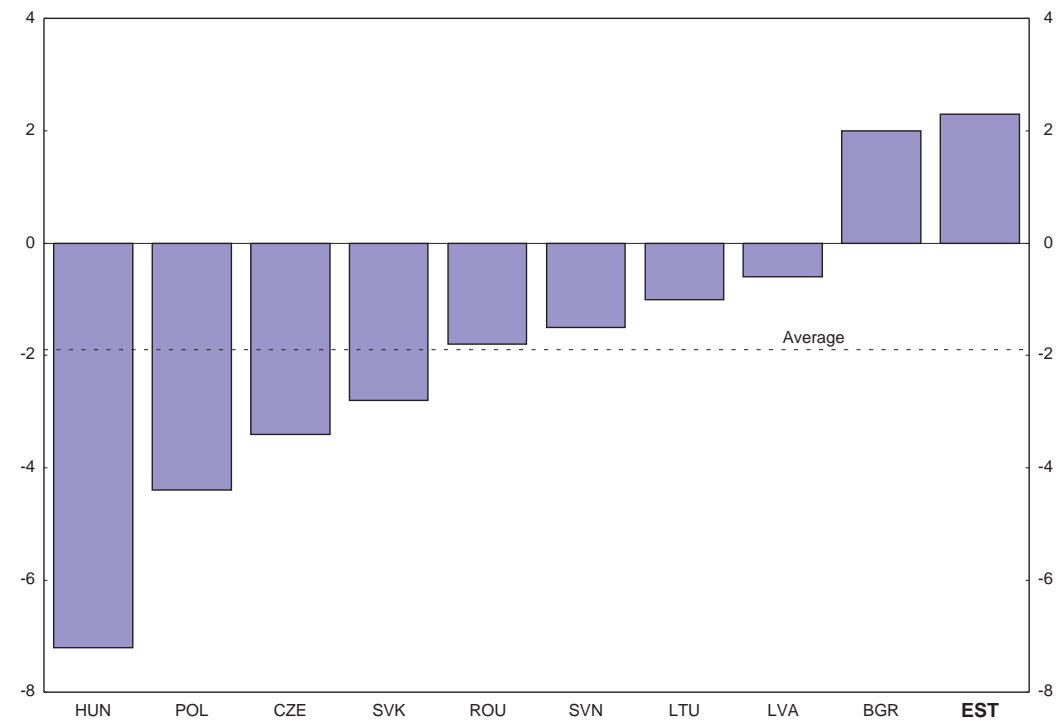

Figure 4b. Gross debt, 2003-07

$\%$ of GDP

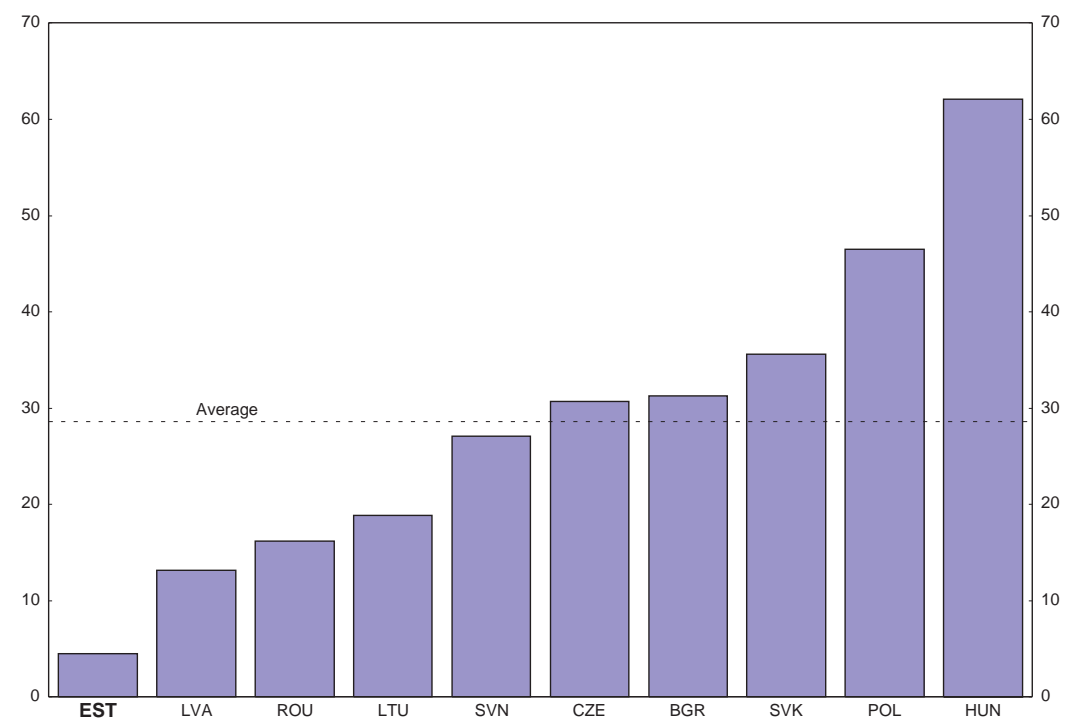


Figure 4c. Correlations of the cyclical components of real government consumption and real GDP

0 to \pm 1 indicating increasing positive/negative correlation

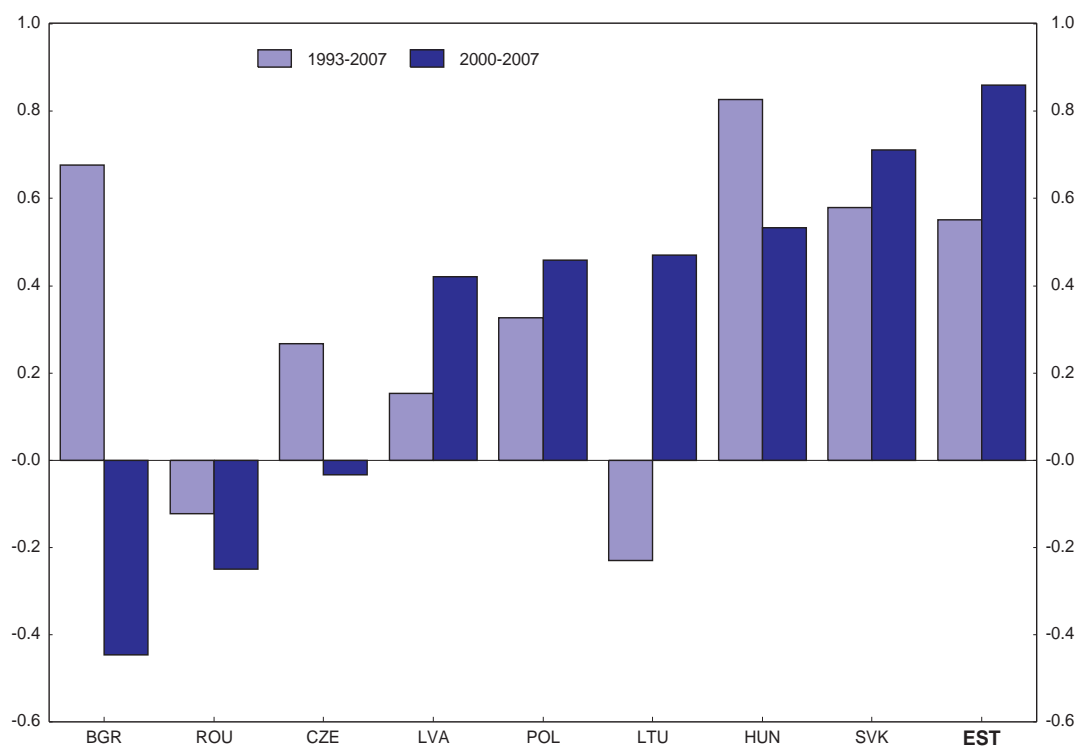

Source: IMF World Economic Outlook and IFS.

\section{Household indebtedness has soared due to a variety of factors}

Household debt grew rapidly during the 2000s, as illustrated by high ratio of housing loans to GDP at the end of 2007 (Figure 5). Between 2004 and 2007, the increase in the stock of housing loans amounted to 20 percentage points of GDP, and household debt jumped up during this period by about 25 percentage points of GDP. The Estonian corporate sector is also heavily indebted, implying that through their shareholdings in enterprises, households ultimately bear many risks associated with the deteriorating corporate sector. ${ }^{24}$

Debt accumulation was the flip side of financial sector reforms and opening the banking sector to foreign investors. Privatization in the mid-1990s put a large majority of the housing stock into private ownership, forming the collateral base for mortgage finance in Estonia (OECD, 2005).

Household borrowing expanded after the Russian crisis when Nordic banks acquired the key domestic banks. Households' optimistic expectations about future incomes, low mortgage rates, favourable tax treatment of interest, and low inflation also played a role (Table 7). New products, in particular those allowing equity withdrawal, added to debt by letting borrowers repay their mortgages slowly. The causes of rising household debt were thus similar to those in OECD

24. The high corporate and household debt separates Estonia from the euro area countries, where household savings increased during the credit expansion and offset the corporate financial deficit (IMF, 2008). 
countries - favourable financial conditions, buoyant housing markets, and supply side innovations in credit markets (Girouard, Kennedy and André, 2006).

The high debt burden has weakened households’ financial position. By mid-2008, household loans amounted to almost $100 \%$ of their financial assets, markedly above regional peers such as the Czech Republic. While borrowing has slowed in 2008 and 2009, the value of financial assets also declined due to plummeting equity prices and a slowdown in deposit growth, resulting in negative net financial worth. ${ }^{25}$

Figure 5. Housing loans, 2007 $\%$ of GDP

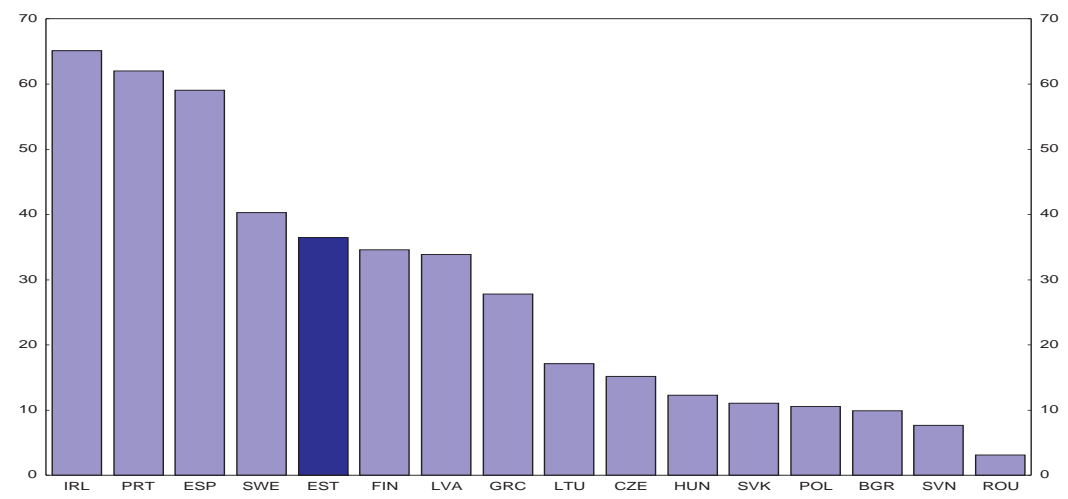

Note: Data for 2008 refers to June and for other years, to December.

Table 7. Household debt, December 2002-September 2008

\begin{tabular}{llllllll}
\hline & Dec-02 & Dec-03 & Dec-04 & Dec-05 & Dec-06 & Dec-07 & Sep-08 \\
\cline { 2 - 7 } As percent of & & & & & & & \\
disposable income & 25.7 & 33.1 & 41.6 & 56.2 & 75.7 & 86.1 & 84.3 \\
As percent of GDP & 13.7 & 17.7 & 21.4 & 30.6 & 40.9 & 46.8 & 48.9 \\
\hline
\end{tabular}

Source: Bank of Estonia.

\section{Macroeconomic implications of high household debt}

The high level of household indebtedness in Estonia has several macroeconomic implications, including a greater sensitivity of private consumption and GDP growth to changes in interest rates. While to some extent high household borrowing constituted a rational response to favourable lending conditions and consumption smoothing, the level of households' indebtedness in Estonia at the end of 2007 far exceeded that of regional peers with similar per capita income, such as the Czech Republic (Table 8). Experiences of other countries suggest that high household indebtedness is unlikely to be a source of a major negative shock to the other sectors of the economy, but it may amplify other shocks, such as fluctuations in income, interest rates and house prices. With variable interest rates, consumption responds quickly to price shocks (Debelle, 2004).

25 For households that purchased their houses in the early 2000s, this was somewhat mitigated by rising net non-financial assets. 
Table 8. Estonia and the Czech Republic: Selected indicators of household indebtedness, end-2007

\begin{tabular}{lcc}
\hline & Estonia & Czech Republic \\
\cline { 2 - 3 } Debt/GDP (\%) & 45.0 & 23.4 \\
Debt / financial assets (\%) & 95.0 & 29.6 \\
Interest expenses / disposable income (\%) $^{1 /}$ & 4.8 & 1.8 \\
Deposits/debt (\%) & 44.5 & 216 \\
Net financial assets/GDP (\%) & 0.7 & 41.1 \\
\hline
\end{tabular}

1. Gross disposable income is used for the Czech Republic; net disposable income for Estonia. Source: The Bank of Estonia and the Czech National Bank.

Several factors mitigate risks stemming from the high household indebtedness. The distribution of the debt is skewed towards households with high incomes, who are less exposed to rises in unemployment or interest rates. ${ }^{26}$ As the maturity of housing loans lengthened, households can maintain same monthly debt service payments while taking out larger loans.

However, the average loan to value (LTV) ratio increased to $90 \%$ for some of the new housing loans extended in recent years. As the house prices continue to fall, some of the newer borrowers are likely to end up with negative equity. The Bank of Estonia and Financial Supervisory Authority should therefore carefully monitor the latest developments in various aggregate indicators of indebtedness, including LTV ratios and ratios of debt to disposable income, and communicate findings to the banking sector and the public. This would increase transparency and also help maintain trust in the financial stability of the banking system.

\section{Financial stability risks related to variable interest rates}

In the current environment of high mortgage debt and the predominantly variable-rate loans, the sensitivity of households to interest rate changes implies a greater default risks and an increased vulnerability of the financial sector. Even if households would not default on loans, an interest rate increase reduces their disposable income, thus affecting overall economic activity.

Through volatility of debt service payments, the variable-rate loans make the household sector directly, and the banking sector indirectly, vulnerable to interest rate changes. ${ }^{27}$ The households bear directly the risk of higher interest rates through larger mortgage payments and smaller net income. The ability of households to maintain debt service payments when interest rate increases depends largely on whether the households anticipated such changes at the time when they applied for the mortgages (Debelle, 2004). As the output decline and unemployment increase are much more pronounced than expected, some payment difficulties are inevitable.

Banks' credit risk rises with the increased use of variable rate loans as banks replace their interest rate risk by higher client default risk. In contrast to variable rates, fixed rates give

26. More recently, the extension of maturities to more than 20 years and reductions in minimum down payment requirements made housing loans accessible to lower income households. Correspondingly, households that took out a loan in recent years seem to be the most vulnerable to adverse shocks.

27. Specifically, a one percentage point rise in short-term interest rates would lead to a 0.8 percentage point increase in the aggregate interest payment-to-disposable income ratio. 
households certainty over the profile of their debt service payments. ${ }^{28}$ However, since the fixed-rate loans entail an interest rate risk for the lender, a premium is required and these loans often ex post turn out to be more expensive.

The current recession has increased risks to financial stability, mainly through rising unemployment and deterioration of disposable income, but also through interest rate increases. To the extent that the house purchases were speculative and households were counting on house price increases for repaying their primary mortgages, the decline in real estate prices will undermine their debt service capacity. However, the share of such speculative loans seems low (measured by second and third mortgages). The deterioration of the construction and the real estate sectors increased the risk of loan defaults by these sectors. As most loans' are backed by mortgages, banks' capacity to extend them is reduced by declining asset prices.

The high household indebtedness, recession, and predominance of variable rates in an environment of rapidly rising unemployment have already led to a rise in the stock of overdue household loans. The share of stock of overdue loans in the household loan portfolio more than doubled from mid-2007, and it reached 7\% in September 2008. On the positive side, the banking sector is well-capitalized, with capital adequacy ratio well above the required minimum of $10 \%$. Although banks have improved provisions as non-performing loans have risen, increases in lending rates and spreads have offset the impact on earnings (IMF, 2009). ${ }^{29}$

\section{Debt sustainability concerns contributed to the abrupt end of the housing boom}

As discussed, by the end of 2007, Estonia had one of the highest private sector debts among the emerging market European countries. Around that time, the Nordic banks reassessed Estonia's outlook including debt sustainability of households and the corporate sector. As a result, they tightened lending conditions, which triggered a sharp downturn in the housing loan market. In response to higher interest rates, households lowered their demand for credit, also because of concerns about declining real estate prices. As a result, growth of housing loans decelerated from 74\% in March 2006 (year-on-year) to 11\% in December 2008. In addition, the credit crunch led to deceleration of real estate transactions, and contributed to collapse of growth (Figures 6a and 6b). By mid-2008, real estate prices were rapidly declining. ${ }^{30}$

28. There is no direct impact of unexpected interest rate increases on households holding fixed-rate loans. However, the households will ultimately bear the risk through their shareholdings in the financial institutions or - in case of securitized mortgages - through the value of pension funds (Debelle, 2004a).

29. As the currency board constrains the Bank of Estonia's ability to provide liquidity support to banks, in February 2009 the Bank signed a precautionary agreement with the Swedish central bank. It allows the Bank to borrow up to 10 billion Swedish kronor against Estonian krooni, thus strengthening its capacity to extend liquidity. Nevertheless, the risks of financial contagion remain.

30. In the 4th quarter of 2008 prices declined by almost 30\% relative to same quarter in 2007. Number of real estate transactions declined in the $1^{\text {st }}$ quarter of 2009 to less then 6,000 - the lowest level since 1997. 
Figure 6a. Credit to households and number of real estate transactions

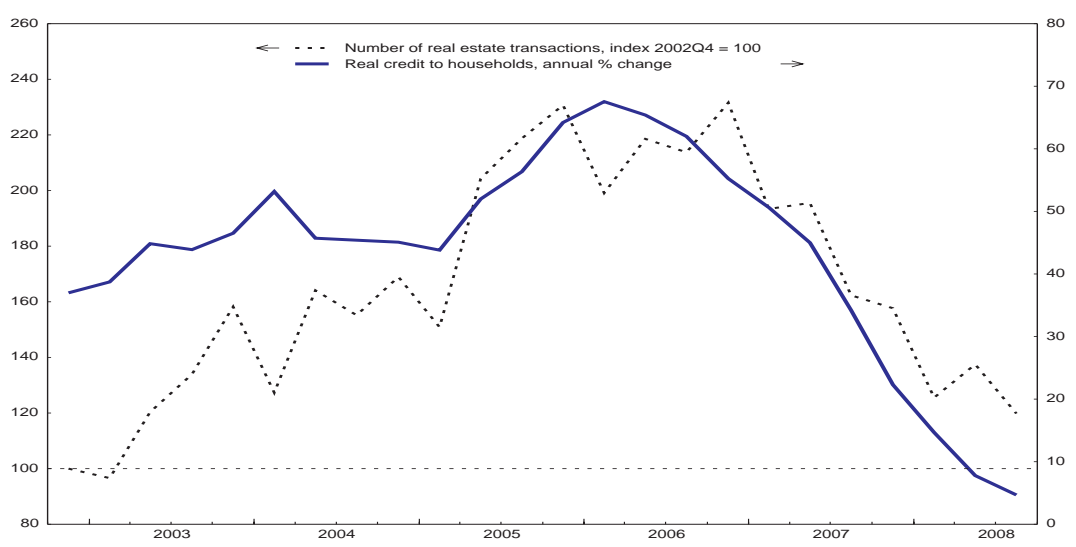

Figure 6b. Household debt, corporate debt and real GDP growth

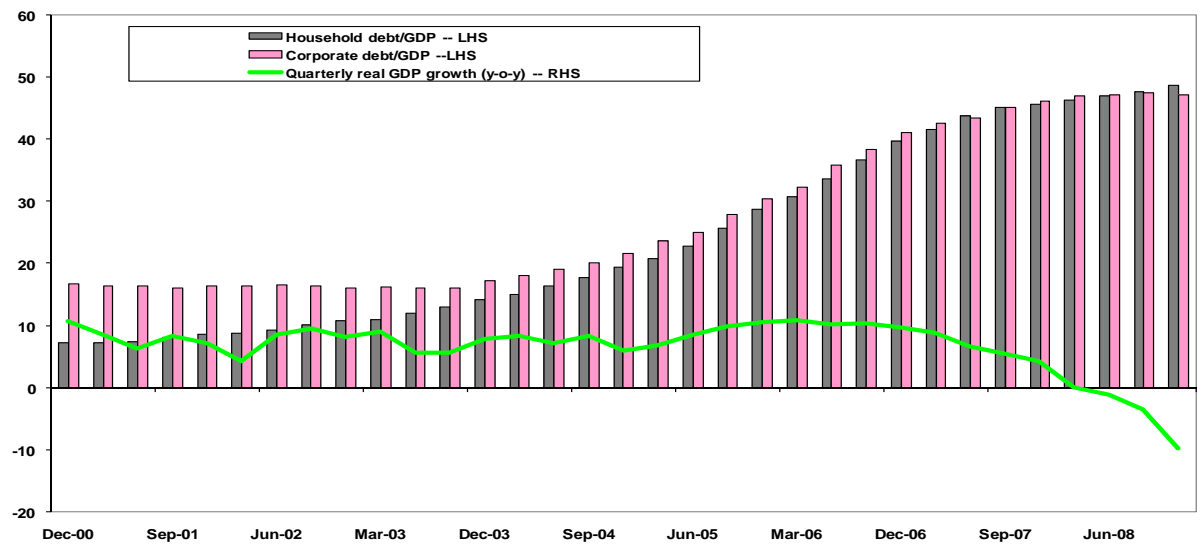

Source: Statistics Estonia.

The combination of plummeting real estate prices and transactions led to a decline in output and jobs in construction, finance and real estate services. The housing market adjustment took place mostly through decline in volumes rather than nominal prices, as is typical in other countries. The abrupt GDP fall in 2008 after the bust in the housing market that Estonia experienced is consistent with evidence from OECD countries that developments in the housing market can have a significant influence on the country's business cycle (Leamer, 2007). According to OECD (2009d) and consensus forecasts, it also seems that Estonia's experience will be consistent with the OECD countries' evidence that housing crises are associated with long lasting recessions and considerable output loss, as discussed in the next section.

What can past housing crises tell us about the Estonian recession?

Based on 23 housing crises in 15 OECD countries between 1970 and 2002, Jannsen (2009) examined the effects of housing crises on the business cycle and found that housing crises usually 
trigger a long lasting recession and a considerable loss in output. ${ }^{31}$ In addition to growth of GDP, private consumption, residential investment, and business investment also dropped sharply at the beginning of a housing crisis and required more than four years to reach pre-crisis level. ${ }^{32}$

A comparison of this typical business cycle pattern during past housing crises with the current one in Estonia indicates that the decline in GDP growth there has been faster and deeper than in OECD countries during 1970-2002. As discussed previously, the recovery will be challenging because of the uncertainties surrounding the global economic and financial crisis.

The boom-bust cycle of the years between 1984 and 1995 in Finland and Sweden can shed some light on Estonia's current situation. The driving forces behind the boom-bust pattern in Finland and Sweden were financial deregulation combined with the maintenance of fixed exchange rate policies that contributed to: i) overheating during the boom phase, with rising inflation and loss of competitiveness; and ii) the financial crisis during the bust phase, with falling output and rising unemployment. Financial developments - credit growth, asset prices and real after-tax lending rates - were the key factors behind the cycle (Jonung et al., 2005). ${ }^{33}$ Both countries experienced domestic banking and currency crises, which were eventually partly solved by devaluation.

Jonung et al. (2005) found that the Finnish-Swedish experience was much more volatile than the average boom-bust pattern. The bust phase in particular was considerably deeper than the average boom-bust in OECD countries between 1970 and 2002, while the recovery came earlier and was more rapid.

While Estonia shares some similarities with the Swedish and Finnish cases, there are also important differences that could ease the recovery. Just like in Finland and Sweden, the boom phase was driven by credit (and capital inflows), rising house prices, and low or even negative real after-tax lending rates. However, according to the recent Financial System Stability Assessment Update for Estonia, financial indicators point to a sound banking sector, and especially strong asset quality and earnings. The system has also proven its resilience during a run on one of the large foreign-owned banks in September 2008, which was promptly resolved due to policy actions of the home Nordic country's central bank (IMF, 2009). At the same time, the global recession and the inability to utilize exchange rate flexibility are additional factors that could slow recovery in Estonia.

With the global financial and economic crisis, euro adoption has again become a widely debated issue. For Estonia, the euro adoption also constitutes an appropriate exit strategy from the currency board, especially since the country already pays most of the cost of the European Monetary Union (EMU) membership. Benefits of joining the EMU include: i) eliminating

31. The start of a housing crisis is defined as the peak of houses prices within a rolling window of eight years, followed by a price decline from the peak of at least $7.5 \%$ during the next four years. Using this definition, the housing crisis in Estonia started in the 3rd quarter of 2007.

32. The author derived the median values of several macroeconomic variables within a time span from 20 quarters before to 20 quarters after the start of a housing crisis. He found that annual GDP reached its bottom in the 2nd year after the price peak with an average growth rate of $0.1 \%$. Accordingly IMF (2003), two years after the outbreak of a housing crisis, output was about $8 \%$ at below the level that could have been reached without a housing crisis.

33. Chapter 3, OECD (2009a) discusses the role that tax incentive for housing played in the accumulation of household debt and in the shift in the production and employment structure of the economy to construction and real estate. 
exchange rate risks; ii) borrowing ECB's credibility in monetary policy; and iii) lowering transaction cost. However, meeting the $3 \%$ limit on the fiscal deficit in the context of falling output will be challenging and implies severe pro-cyclical cuts.

\section{Improving functioning of the housing finance market}

This section examines to what extent the structure of the housing finance market has contributed to the risks discussed above and in particular to accumulation of high household debt predominantly at variable rates. It then discusses medium term policy options to mitigate some of these risks in the future.

\section{Characteristics of the housing finance market}

Institutional characteristics of mortgage markets reflect the local conditions of the financial sector and prevailing financial products, and thus vary widely across countries.

The Estonian financial sector is dominated by foreign-owned commercial banks, with the four largest banks accounting for 97\% of the housing loan market in 2007 (Tamm, 2007). ${ }^{34}$ The housing loan market is characterized by variable-rate loans denominated in foreign currency, with high maximum LTV ratio and long maturity (Table 9). According to IMF (2004), countries with mostly adjustable-rate mortgages experience higher house price growth and volatility than countries with mostly fixed-rate mortgages.

Table 9. Institutional characteristics of national mortgage markets

\begin{tabular}{|c|c|c|c|c|c|c|}
\hline & \multicolumn{2}{|c|}{ Fin. sector indicators } & \multicolumn{4}{|c|}{ Mortgage products } \\
\hline & $\begin{array}{l}\text { Maximum } \\
\text { LTV }(\%)\end{array}$ & $\begin{array}{l}\text { Typical } \\
\text { maturity } \\
\text { (years) }\end{array}$ & $\begin{array}{c}\text { Typical rate } \\
\text { (fixed/variable) }\end{array}$ & $\begin{array}{c}\text { Equity } \\
\text { withdrawal } \\
(\mathrm{Y} / \mathrm{N})\end{array}$ & $\begin{array}{l}\text { Restrictions on } \\
\text { early payments } \\
(\mathrm{Y} / \mathrm{N})\end{array}$ & $\begin{array}{c}\text { Mortgage } \\
\text { bond markets } \\
(\mathrm{Y} / \mathrm{N})\end{array}$ \\
\hline $\begin{array}{l}\text { Estonia } \\
\text { Czech }\end{array}$ & 95 & $20-30$ & variable & Yes & yes & no \\
\hline Republic & $70-100$ & $20-25$ & fixed & no & yes & yes (limited) \\
\hline Hungary & 100 & 15 & variable & yes & no & yes (limited) \\
\hline $\begin{array}{l}\text { Poland } \\
\text { Slovak }\end{array}$ & $>100$ & 20 & variable & $\begin{array}{l}\text { yes, but } \\
\text { rarely used } \\
\text { yes, but }\end{array}$ & $\begin{array}{l}\text { fees allowed, } \\
\text { but rarely used }\end{array}$ & yes (limited) \\
\hline Republic & 70 & 15 & variable & rarely used & no & yes (limited) \\
\hline Latvia & 100 & $20-40$ & variable & yes & $\begin{array}{l}\text { no explicit } \\
\text { regulations }\end{array}$ & yes (limited) \\
\hline Lithuania & 100 & $20-25$ & variable & yes & $\begin{array}{l}\text { no } \\
\text { creditor }\end{array}$ & no \\
\hline Finland & $75-80$ & $15-20$ & variable & yes & compensated & yes (limited) \\
\hline Sweden & $60-80$ & $<30$ & variable & yes & no & yes (limited) \\
\hline
\end{tabular}

Source: IMF (2008) and OECD (2005).

34. This high degree of concentration exceeds that of most European emerging market countries, where $70-80 \%$ of the housing market share is captured by 5 largest banks. It is comparable to Denmark and Sweden, where the 5 largest banks account for more than $90 \%$ of the housing market (IMF, 2007). 


\section{Reducing share of variable-rate loans through developing the housing finance market}

On the demand side of mortgage markets - borrowers usually opted for variable interest rate loans in foreign currency since they experienced mostly declining interest rates and steady exchange rate for years. They may have not fully realized the risks associated with these loans. ${ }^{35}$

More generally, the attractiveness of the different products for households depends partly on the costs of repaying a loan early or of re-financing. In Estonia, these costs are high - the law requires that the cost caused to the lender by early prepayment of the loan must be borne by the borrower (Tamm, 2007). In an environment with declining interest rates that prevailed in Estonia until mid-2005, myopic expectations, the high refinancing costs and limitations on early loan repayment encouraged households to opt for variable-rate instead of fixed-rate loans.

The supply side of mortgage markets is a key factor behind the prevalence of adjustable rate mortgages. In contrast to most other European emerging market economies, Estonia has not developed mortgage bond markets. Banks have thus relied mostly on short-term deposits for financing long-term housing loans, supplemented by short-term loans from parent bank groups.

Under such funding system, lenders tend to offer variable-rates mortgages to reduce their own interest risks, which they pass onto the customers. The banks therefore offer variable interest rates to mitigate their interest rate risk. The share of variable rate loans could thus be reduced by shifting to long-term capital market funding and narrowing the term gap between funding and lending. Such move would entail developing mortgage securities markets, in particular markets with covered bonds.

Mortgage covered bonds are schemes in which bonds backed by mortgages pooled by lenders are sold to investors through a secondary market. Loan assets - and hence credit and prepayment risks - remain on the lender's balance sheet, enhancing incentives for prudent assessment of such risks. The use of mortgage bonds in financing mortgage loans has two merits. One is that bond issues normally can raise longer-term funds than the collection of deposits, which are generally shorter-term in Estonia or than short-term foreign loans. This should help alleviate the duration mismatch between the assets and liabilities of the banks, improving their risk management. The other merit - once the markets stabilize - is the possibility of attracting more funds from foreign investors, and thus benefiting from the increasingly globalized financial markets (OECD, 2005; and European Central Bank, 2009). ${ }^{36}$

\section{Conclusions}

The current recession notwithstanding, Estonia's longer-term economic performance has been exceptional, with one of the highest growth rates in Europe and declining poverty. However, growth was unbalanced and collapsed in 2008. The boom-bust cycle was driven by massive capital inflows under the currency board, which fuelled credit and housing boom. The driving

\footnotetext{
35 The financial deepening was fast and the lending boom was characterized by unusually low interest rates, in particular for variable loans in foreign currency. As in other countries, households may have been looking at only initial monthly payments or assuming the interest rates will remain low.
}

36. Mortgage bond financing requires strong legal settings and a broad investor base. Moreover, development of the government bond market would provide useful benchmark. 
factors of the credit boom were rapid income growth, increasingly negative real interest rates, and on the part both Nordic lenders and Estonian borrowers an overly optimistic assessment of the economic outlook. A tightening of lending conditions led to steep decline in construction and real estate related activities, which has spread to other sectors. These domestic factors were further exacerbated by the marked deterioration of the external environment due to the onset of the global economic and financial crisis, bringing Estonia into a deep recession.

A key challenge for policymakers now is to restore high and sustainable growth, while reducing volatility. This will be challenging due to the existence of external and internal imbalances, and especially distortions that led to the excessive private sector indebtedness.

To bring the economy back on track, Estonia will need to rebalance its resources from nontradables, and in particular construction and real estate, towards exports. Flexibility of the economy will thus be crucial, and so will be the gradual shift to an effective counter-cyclical fiscal policy. ${ }^{37}$ Over the medium term, policymakers could also strengthen incentives for a better functioning of the housing finance market by encouraging longer-term financing of mortgages. The aim of such measures is to reduce the financial stability risks associated with household debt, which in Estonia stem also from the almost exclusive use of variable interest rates and foreigncurrency loans. Furthermore, gradually removing the pro-cyclical bias of fiscal policy would help avoid exacerbating welfare reducing boom-bust cycles.

37. For detailed recommendations in the fiscal policy area in Estonia, see OECD (2009a). 


\section{REFERENCES}

Amato, J.D. and C.H. Furfine (2004), “Are credit ratings procyclical?”, Journal of Banking and Finance, Vol. 28, Issue 11, 2641-2677.

Debelle, G. (2004), “Household debt and the macroeconomy”, BIS Quarterly Review, pp. 51-64, March.

Egert, B. and D. Mihaljek (2006), "Determinants of house prices in Central and Eastern Europe”, BIS Working Papers No. 236.

Eisenbeis, R. A. (2006), "Home country versus cross-border negative externalities in large banking organization failures and how to avoid them", Federal Reserve Bank of Atlanta Working Papers \#18.

European Central Bank (2009), "Housing finance in the euro area”, Occasional Papers No. 101.

European Central Bank (2003), Structural factors in the EU household markets, ECB, Frankfurt, March.

European Commission (2008), "Estonia: Macroeconomic fiscal assessment - An analysis of the December 2008 update of the convergence programme”, ECFIN/50721/09-EN.

European Commission (2006), "Numerical fiscal rules in 25 EU member States”, in Public Finance in EMU, European Commission, Brussels.

Fatas, A. (2005), "Is there a case for sophisticated balanced-budget rules?”, Economics Department Working Papers, No. 466, OECD, Paris.

Ferri, G., L.G. Liu and J.E. Stiglitz, (1999), "The procyclical role of rating agencies: Evidence from the East Asian crisis”, Economic Notes, Vol. 28, No. 3, 335-355.

Girouard, N., M. Kennedy and C. André (2006), “Has the rise in debt made households more vulnerable?”, OECD Economics Department Working Papers, No. 535, Available at www.olis.oecd.org/olis/2006doc.nsf/linkto/eco-wkp(2006)63.

Gulde, A-M. (2005), “Financial stability arrangements in Europe: A review”, Proceedings of the Austrian National Bank workshops (4/2005).

Hegert, S.W. (2009), "Capital inflows, exchange market pressure, and credit growth in four transition economies with fixed exchange rates", Economic Systems, forthcoming.

International Monetary Fund (2009), “Republic of Estonia: Financial system stability assessment”, IMF Country Reports, No. 09/89.

International Monetary Fund (2008), Global financial stability report, IMF, Washington, DC, October.

International Monetary Fund (2007), "Denmark: financial sector assessment program technical note - the Danish mortgage market - a comparative analysis”, IMF Country Reports, No. 07/123.

International Monetary Fund (2004), World Economic Outlook, September.

International Monetary Fund (2003), “When Bubbles Burst”, World Economic Outlook, April. 
Jaeger, A. and A. Klemm (2007), “Assessing the fiscal stance during the absorption boom”, in Bulgaria: Selected Issues, IMF Country Reports No. 07/390, pp. 44-53.

Jacobsen, D. H. and B. E. Naug (2005), “What drives house prices?” Economic Bulletin of the Central Bank of Norway, 05/Q1.

Jannsen, N. (2009), “National and international business cycle effects of housing crises”, Kiel Working Papers, No. 1510.

Jonung, L.; L. Schuknecht and M. Tujula (2005), "The boom-bust cycle in Finaland and Sweden 1984-1995 in an international perspective”, CFS Working Papers, No. 2006/13.

Kaminsky, GL., C. Reinhart and CA. Vegh (2004), "When it rains it pours: procyclical capital flows and macroeconomic policies”, NBER Macroeconomics Annual 2004, The MIT Press, Cambridge, MA.

Kiyotaki, N. and J. Moore (1997), “Credit cycles”, Journal of Political Economy, Vol. 105, No. 2, pp. 211-248.

Kuenzel, R. and B. Bjornbak (2008), “The UK housing market: Anatomy of a house price boom”, ECOFIN Country Focus, Vol. 5, Issue 11.

Lamine, B. (2008), “Estonia: overheating and sectoral dynamics”, ECOFIN Country Focus, Vol. 5, Issue 7 $(8 / 1 / 2008)$.

Leamer, E. (2007), “Housing is the business cycle”, NBER Working Papers, No. 13428.

Malzubris, J. (2008), “Ireland's housing market: bubble trouble”, ECOFIN Country Focus, Vol. 5, Issue 9.

Meen, G. (2002), “The time-series behavior of house prices: Transatlantic divide”, Journal of Housing Economics, Vol. 11(1), pp 1-23.

Organisation for Economic Cooperation and Development (2009a), OECD Economic Surveys-Estonia, OECD, Paris.

Organisation for Economic Cooperation and Development (2009b), OECD Economic Surveys—Slovak Republic, OECD, Paris.

Organisation for Economic Cooperation and Development (2009c), OECD Economic Surveys-Euro area, OECD, Paris.

Organisation for Economic Cooperation and Development (2009d), Interim Economic Outlook - March 2009, OECD, Paris.

Organisation for Economic Cooperation and Development (2008), OECD Economic SurveysNetherlands, OECD, Paris.

Organisation for Economic Cooperation and Development (2007), OECD Economic Surveys—Sweden, OECD, Paris.

Organisation for Economic Cooperation and Development (2006), OECD Economic Surveys_- Ireland, OECD, Paris. 
Organisation for Economic Cooperation and Development (2005), Housing finance markets in transition economies: trends and challenges, OECD, Paris.

Pagano, M. and Volpin, P. (2009), “Credit ratings failures: Causes and policy options”, in M. Dewatripont, $\mathrm{X}$. Freixas, and R. Portes (editors): Macroeconomic Stability and Financial Regulation: Key Issues for the G20,; CEPR, London.

Reinhart, C.M. and K.S. Rogoff (2008), "Is the 2007 US sub-prime financial crisis so different? An international historical comparison”, NBER Working Papers, No. 13761.

Ross, M. (2009), “Estonia has the prerequisites for being among the first ones exiting the crisis”, Bank of Estonia Press releases, 11 March.

Schoenmaker, D. and S. Oosterloo (2006), 'Financial supervision in Europe: Do we need a new architecture?’, Cahier Comte Boël, No. 12, European League for Economic Co-operation, Brussels.

Tamm, M. (2007), “Housing finance in Estonia: A short note on recent developments”, Kroon\&Economy, Vol. 2, pp. 18-27.

Tornell, A. and F. Westermann (2005), Boom-Bust Cycles and Financial Liberalization, MIT Press, Cambridge, MA.

White, W. (2006), "Measured wealth, real wealth and illusion of saving”, IFC Bulletin No. 26, pp. 1-11. 


\section{DAVIDSON INSTITUTE WORKING PAPER SERIES - Most Recent Papers}

The entire Working Paper Series may be downloaded free of charge at: www.wdi.umich.edu

CURRENT AS OF 8/27/09

\begin{tabular}{|c|c|c|}
\hline Publication & Authors & Date \\
\hline $\begin{array}{l}\text { No. 965: Capital inflows, household debt and the boom-bust cycle in } \\
\text { Estonia }\end{array}$ & $\begin{array}{l}\text { Zuzana Brixiova, Laura Vartia } \\
\text { and Andreas Worgotter }\end{array}$ & July 2009 \\
\hline No. 964: Labour Market Felxibility in Estonia: What More Can be Done? & Zuzana Brixiova & July 2009 \\
\hline $\begin{array}{l}\text { No. 963: Market Globalization by Firms from Emerging Markets \& Small } \\
\text { Countries: An Application of the Neoclassical Trade Model }\end{array}$ & Tamir Agmon & July 2009 \\
\hline $\begin{array}{l}\text { No. 962: Central Bank Communication and Exchange Rate Volatility: A } \\
\text { GARCH Analysis }\end{array}$ & $\begin{array}{l}\text { Roman Horvath and Radovan } \\
\text { Fiser }\end{array}$ & July 2009 \\
\hline $\begin{array}{l}\text { No. 961: On the influence of oil prices on stock markets: } \\
\text { Evidence from panel analysis in GCC countries. }\end{array}$ & $\begin{array}{c}\text { Christophe Rault and Mohamed } \\
\text { El Hedi Arouri }\end{array}$ & June 2009 \\
\hline $\begin{array}{l}\text { No. 960: Oil Prices \& Stock Markets: What Drives What in the Gulf } \\
\text { Corporation Council Countries? }\end{array}$ & $\begin{array}{l}\text { Christophe Rault and Mohamed } \\
\text { El Hedi Arouri }\end{array}$ & June 2009 \\
\hline $\begin{array}{l}\text { No. 959: Trade Specialisation And Economic Convergence: } \\
\text { Evidence From Two Eastern European Countries }\end{array}$ & $\begin{array}{l}\text { Christophe Rault, Guglielmo } \\
\text { Caporale, Robert Sova \& } \\
\text { Anamaria Sova }\end{array}$ & June 2009 \\
\hline $\begin{array}{l}\text { No. 958: Inflation differentials in the Euro area and their determinants } \\
\text { - an empirical view }\end{array}$ & $\begin{array}{c}\text { Juan Ignacio Aldasoro \& Václav } \\
\text { Žd'árek }\end{array}$ & April 2009 \\
\hline No. 957: Infrastructure and growth: Empirical evidence & $\begin{array}{c}\text { Balazs Egert, Tomasz } \\
\text { Kozluk and Douglas Sutherland }\end{array}$ & April 2009 \\
\hline $\begin{array}{l}\text { No. 956: Infrastructure investment in network industries: The role of } \\
\text { incentive regulation and regulatory independence }\end{array}$ & Balazs Egert & April 2009 \\
\hline $\begin{array}{l}\text { No. 955: The impact of monetary and commodity fundamentals, macro } \\
\text { news and central bank communication on the exchange rate: } \\
\text { Evidence from South Africa }\end{array}$ & Balazs Egert & April 2009 \\
\hline $\begin{array}{l}\text { No. 954: "Family" ownership, tunneling and earnings management: } \\
\text { A review of the literature }\end{array}$ & $\begin{array}{l}\text { Sumon Bhaumik and Andros } \\
\text { Gregoriou }\end{array}$ & $\begin{array}{l}\text { March } \\
2009\end{array}$ \\
\hline $\begin{array}{l}\text { No. 953: Impact of Foreign Direct Investments on Industrial Productivity: } \\
\text { A Subnational Study of India }\end{array}$ & Krishna C. Vadlamannati & $\begin{array}{l}\text { March } \\
2009\end{array}$ \\
\hline $\begin{array}{l}\text { No. 952: Determinants of Exchange Rate Practices in the MENA } \\
\text { Countries: Some Further Empirical Results }\end{array}$ & Sfia, M. Daly and Mouley Sami & Jan 2009 \\
\hline No. 951: An Analytic Approach To Selecting A Nonprofit & $\begin{array}{l}\text { Andrés Ramírez and } \\
\text { Hakan Saraoglu }\end{array}$ & Jan 2009 \\
\hline $\begin{array}{l}\text { No. 950: Anthropometry of Love } \\
\text { Height and Gender Asymmetries in Interethnic Marriages }\end{array}$ & Michèle Belot and Jan Fidrmuc & Jan 2009 \\
\hline No. 949: Is THE COST OF LIVING IN RUSSIA REALLY THAT LOW? & Konstantin Gluschenko & Dec 2008 \\
\hline $\begin{array}{l}\text { No. 948: Banking Market Liberalization and Bank Performance: the Role } \\
\text { of Entry Modes }\end{array}$ & Ngoc-Anh Vo Thi & Jan 2009 \\
\hline $\begin{array}{l}\text { No. 947: The Monetary Union: The Decade Ahead. } \\
\text { The Case of Non-Member States }\end{array}$ & Daniel Daianu and Laurian Lungu & Jan 2009 \\
\hline No. 946: Currency Substitution: A Case Of Kazakhstan (2000:1-2007:12) & $\begin{array}{l}\text { Mesut Yilmaz, Yessengali } \\
\text { Oskenbayev \& Kanat Abdulla }\end{array}$ & Jan 2009 \\
\hline $\begin{array}{l}\text { No. 945: Determinants Of Pollution Abatement And Control Expenditure: } \\
\text { Evidence From Romania }\end{array}$ & $\begin{array}{l}\text { Guglielmo Caporale, Christophe } \\
\text { Rault, Robert Sova \& Anamaria } \\
\text { Sova }\end{array}$ & Jan 2009 \\
\hline $\begin{array}{l}\text { No. 944: Bootstrap panel Granger-causality between government } \\
\text { spending and revenue in the EU }\end{array}$ & $\begin{array}{l}\text { Antonio Afonso and Christophe } \\
\text { Rault }\end{array}$ & Jan 2009 \\
\hline No. 943: Regional Determinants of FDI Distribution in Poland & $\begin{array}{l}\text { Agnieszka Chidlow and Stephen } \\
\text { Young }\end{array}$ & Nov 2008 \\
\hline No. 942: Structural Reform and Firm Exports & $\begin{array}{l}\text { Alvaro Cuervo-Cazurra \& Luis } \\
\text { Alfonso Dau }\end{array}$ & Sept 2008 \\
\hline
\end{tabular}

